

http://www.dggs.dnr.state.ak.us

Vol. 8, No. 2, September 2005

\title{
A SUMmary OF THE PAST, PRESENT, AND FUTURE OF Distributing Alaskan GEOLOGIC DATA IN DIGITAL FORMAT
}

Kenneth Papp ${ }^{1}$

The Alaska Division of Geological \& Geophysical Surveys (DGGS) has collected and published a wealth of geologic research and information about the geology, natural resources, and geologic hazards of Alaska over the last century. The maps, reports, and informational publications produced by the U.S. Geological Survey (USGS) in Alaska are widely utilized by oil, mining, and resource-based companies, as well as consultants, universities, schools, government agencies, scientists, and private individuals. These users have become more technologically savvy over time and, as a result, user requests for digital data in addition to or in lieu of paper reports have grown exponentially. This newsletter will briefly discuss the origin of the DGGS geologic database system, current digital geologic data-distribution tools, and future prospects in loading, managing, and distributing digital geologic data to the wide variety of users in the years to come.

\section{BACKGROUND}

In striving to meet user demands, DGGS realized that current methods of archiving the division's data were inefficient, lacked organization, and were poorly documented (Davidson, 1998). To meet the digital data distribution and archival needs of the 21st century, DGGS needed to determine how such a large amount of data could be easily stored and distributed and what would be the most cost- and time-effective method for data distribution. In the late 1990s DGGS concluded that the amount of new and legacy geologic data that the division produces and manages warranted a division-wide computer database system. As a result, the Geologic and Earth Resource Information Library of Alaska (GERILA) geologic information database project was initiated in October 2000 (Freeman, 2001a).

The GERILA database system was designed to provide consistent input, organization, and a storage infrastructure for the new and legacy geologic data generated by DGGS geologists. Additionally, the system provides a means for both the public and in-house users to find and identify the type and geographic locations of geological data available from DGGS. The GERILA database design team interviewed DGGS scientists and work groups to determine the overall layout and organization of the database structure and developed the data model accordingly (Freeman, 2001b). The implementation of the system's structure, hardware, software, and data loading utilities were finalized in May 2002. In the intervening time DGGS staff has methodically loaded data into the database.

The GERILA database has successfully evolved since its initiation and has become a primary clearinghouse for distributing Alaskan geologic data in digital formats to both internal users and to the general public (Freeman and others, 2003). The ongoing database metamorphosis has been a result of rapid growth in (1) the expanding needs of geoscientists and industry for data that can be utilized by Geographic Information System (GIS) software and mapping technologies, (2) an increase in computer hard drive storage and network bandwidth capabilities, and (3) growing user expectations for online data availability. Figure 1 graphically depicts the central role of the DGGS GERILA database to a number of branching subsystems and user interfaces.

\section{THE PRESENT}

Currently the GERILA database houses more than 4,800 references, 2,800 documents, 4,850 maps, and 3,550 geochemical sample analyses. Users throughout the country can now access Alaskan geologic data on-line through several means:

1. The DGGS publications pages: An online library and search interface that allows users to search for DGGS and Alaskan USGS publications. Reports, maps, and data can be viewed, downloaded, or ordered on paper via a downloadable order form. On-line link: http:// wwwdggs.dnr.state.ak.us/pubs/pubs.jsp

2. WebGeochem: An on-line geographic and thematic search tool for DGGS geochemical data based on sample type, analysis type, and either a geographic area or a preexisting collection of geochemical data. Users can view selected geochemical data in tabular form with links to documentation of the sample, analysis source, bibliographic source, and analytical methods used. On-line link: http:// wwwdggs.dnr.state.ak.us/webgeochem/index.jsp

\footnotetext{
${ }^{1}$ Alaska Division of Geological \& Geophysical Surveys, 3354 College Rd., Fairbanks Alaska 99709-3707. 


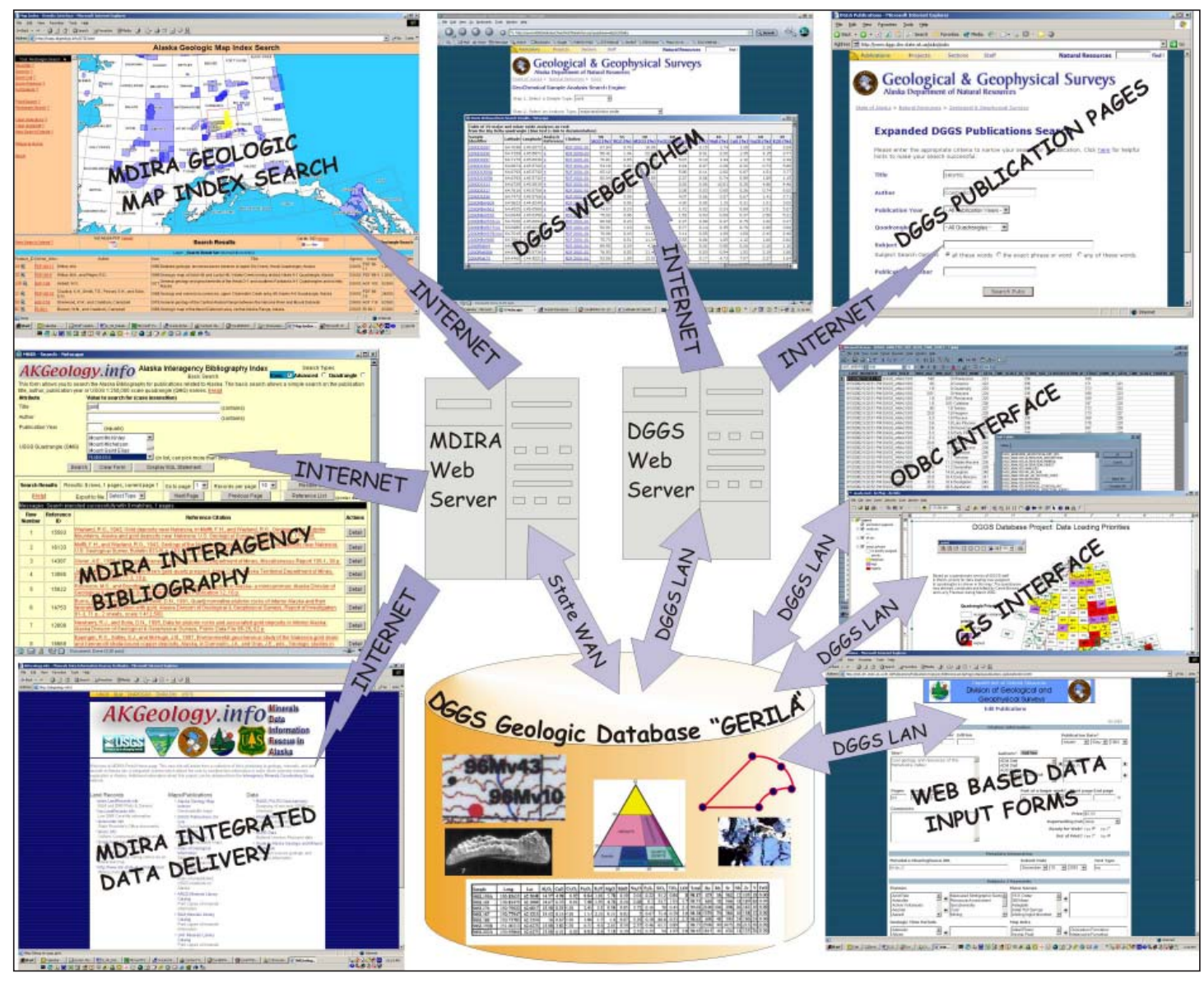

Figure 1. Geology and Earth Resources Information Library of Alaska (GERILA) database provides fresh information to many public web pages that distribute geologic publications and data.

3. The Alaska Map Index Project: An on-line searchable index of published geologic maps in Alaska. The index interface allows searches by theme and map-based geographic search with links to maps that are available on-line. On-line link: http://maps.akgeology.info/

These three DGGS database search engines (described in further detail below) allow users to generate custom queries to search for data, get quick access to the desired data, and download or order the data in a minimal amount of time. These tools are all available at http://akgeology.info/, a portal created with the help from federal funding from the Minerals Data and Information Rescue in Alaska program (MDIRA) to rescue datasets from USGS, BLM, and other DNR sections.

\section{DGGS Publications Pages}

In 1999, DGGS began a massive scanning project to convert our 85 years of legacy publications to digital format, thus allowing the data to be available to the public via the Internet. In 2002 the scanning project was expanded to include Alaska related USGS Professional Papers and Bulletins. DGGS's newest reports are generated directly from the original vector or text document files. Current file formats used for reports and maps are Adobe Acrobat Portable Document Format (PDF) and LizardTech's MrSID. At the time of this writing DGGS has decided to phase out the MrSID format and continue with the PDF for all new and future publications.

Publication files were originally indexed and offered to the public through static HTML pages. However, the expansion of the GERILA database has enabled us to move to "live" pages, meaning they are generated by the Java programming language and updated in near-real time based on criteria assigned by the user. Now, as new publications become available, the bibliographic and corresponding map information, if any, are entered directly into the GERILA database. This process allows the publication to become instantly viewed, downloaded, or ordered on-line.

Contact: Simone Montayne, Geologist, Alaska Division of Geological \& Geophysical Surveys, (907) 451-5027, Simone_Montayne@dnr.state.ak.us

\section{WebGeochem}

Released in June 2005, WebGeochem is a new addition to the suite of on-line query tools that DGGS provides to internal staff and outside users. Acting as an interface to the DGGS GERILA database, the WebGeochem tool efficiently consolidates a large number of rock and sediment sample analyses, which currently include published data from the 1991 Land Selection Project. Additional geochemical data, spanning the last 20 years of DGGS publications, will be loaded into the 
central database. Analyses include samples originating from drill core, pan concentrate, rock, soil, and stream sediment, allowing the user to query these samples to obtain trace element and major/minor oxide results.

After the user determines the sample and analysis type, he or she can choose the spatial extent of the search or select from a known list of projects that have yielded geochemical results. When the user finishes making his/her query selections and pressing the "Submit Request" button, a new window opens displaying the query results in table format (fig. 2). The result, in this example, is a table of 16 major oxide, minor oxide, and trace element analyses on rock samples from publication PDF 93-8. Within the table are links to additional information or documentation regarding the Sample Identifier (sample type, description, latitude and longitude, geodetic horizontal datum, and field locality identifier), Analysis Reference (analysis methodology), Citation (including a link to the publication on the DGGS web site), and Chemical Species (for example, $\mathrm{SiO}_{2}$, including analysis methods, sample preparation notes, units, detection limits, and comments). The purpose of compiling these data and distributing them on the Internet is to stimulate the economic development that results from successful mineral exploration and new mineral discoveries. In addition, the on-line presentation and organization of these data will highly benefit those performing scientific research in geochemistry, volcanology, petrology, and hydrology in both the private and academic communities.

Contact: Larry Freeman, Geologist, Alaska Division of Geological \& Geophysical Surveys, (907) 451-5027, lawrence_freeman@dnr.state.ak.us

\section{The Alaska Map Index Project}

As the name implies, the goal of the Alaska Map Index Project is to identify the current status of statewide bedrock and surficial geologic mapping and present this information to the mineral industry and academia. There was no up-todate index of DGGS, USGS, U.S. Bureau of Land Management (BLM), and U.S. Bureau of Mines (BOM) bedrock and surficial geologic maps before this project began. The multi-agency database now houses more than 950 geologic maps of Alaska and contains 95 percent of DGGS published maps. The map outlines were produced using the digital mapping software MapInfo and care was made to enter the actual area of mapping instead of the map sheet boundaries. As a result, the outline may look different from the published map sheet, but more accurately reflects the true status of geologic knowledge.

The Map Index web page gives users two main search options: a text-based query form and an interactive map-based search (fig. 3). The text-based query form allows the user to choose from five different map types and several sub-types. The map-based search tool provides the user with spatial tools to zoom and center the map, limit the search region with a rectangle or point, or select mapped regions with their mouse. If the Feature ID number is clicked on in the search results at the bottom portion of the page, the corresponding map area is highlighted in the map window. In addition, the search results provide links to the location of the publications on the DGGS web site, allowing the user to easily download or order the available digital or printed report and map. Over the next six months U.S. Geological Survey, U.S. Bureau of Land Management, and U.S. Bureau of Mines geologic maps will

\section{WebGeochem: DGGS Geochemical Sample Analysis Search}

Step 1. Select a Sample Type:

(press Ctrl and left mouse button

to select multiple sample types)

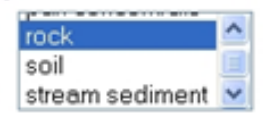

Submit

You have selected rock sample type

Step 2. Select an Analysis Type:

(press Ctrl and left mouse button

to select multiple analysis types)

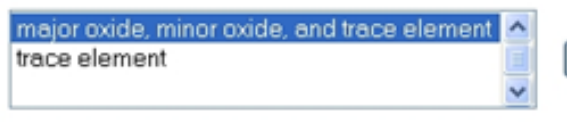

Submit

You have selected major oxide, minor oxide, and trace element analysis type

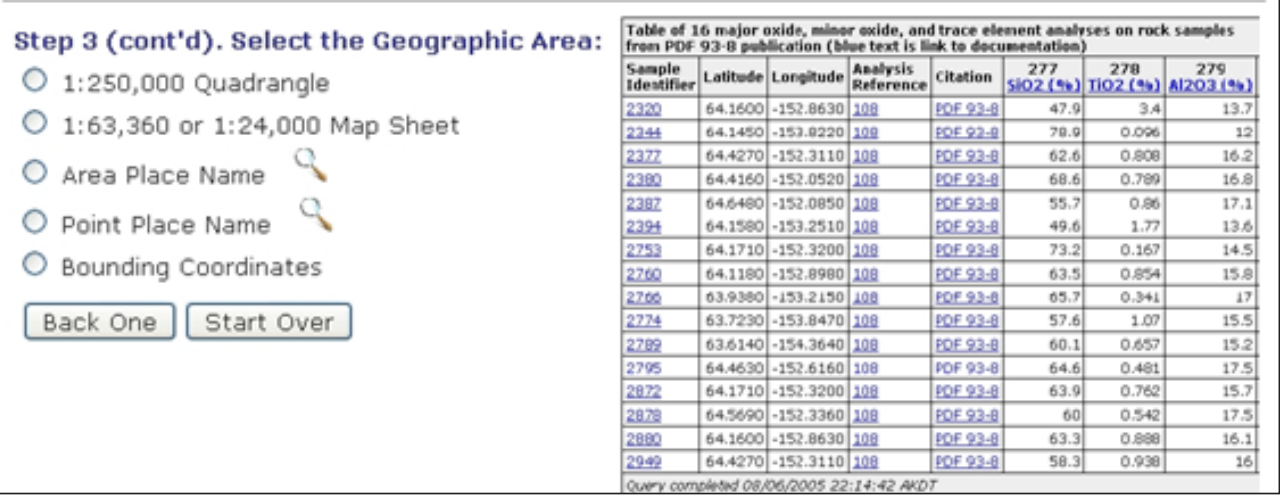

Figure 2. The three-step selection process to query geochemical sample analyses using the DGGS WebGeochem search engine. An example of the search results in tabular form is also shown, where blue, underlined text represents links to additional information. 




be loaded and the index will be moved into the DGGS GERILA database, allowing for full search functionality. The goal of the Map Index Project is to compile an updated spatial archive of the mapped regions of Alaska and allow users to quickly query, identify, and acquire the available data.

Contact: Laurel Burns, Chief, Minerals Section, Alaska Division of Geological \& Geophysical Surveys, (907) 451-5021, laurel@dnr.state.ak.us

\section{THE FUTURE}

What does the future hold for the DGGS digital geologic data distribution program? One of DGGS's top priorities is to be as complete and up to date as possible regarding the archiving and distribution of Alaskan geological and geophysical information. The following four projects are currently funded through the MDIRA Program and will be initiated during the coming year:

- Digital Geospatial Data Distribution - A focused effort is currently underway to upgrade the DGGS web site to provide users with the digital data used to create the geological and geophysical maps in the form of ArcGIS shape files, raster images (i.e. GeoTIFF), and metadata as compressed files for download via the World Wide Web "on the fly."

- USGS Publications Scanning Project - This project is currently taking on the arduous task of converting Alaskan USGS Open File Reports, USGS Folio Maps, and Mineral Industry Research Laboratory (MIRL) reports and maps from printed to digital format. Once completed, this portion of the project will generate an additional 4,000 references into the DGGS database.

- Geochronology database - This database will house isotopic geochronologic data and serve it through a web-based interface similar to WebGeochem. Data collection will commence in Fall 2005.

- Geological Materials Catalog - This will provide a complete digital inventory of mineral industry core and DGGS surficial geological samples. This inventory will be integrated with field locality and analytical information in the DGGS database and a web-based search engine will be provided.

In addition, DGGS is currently planning additional projects to leverage the existing database and web architec- 
ture put in place by MDIRA. Such projects include a searchable organic geochemical database to include data from sample analyses that will provide information about the thermal maturity of potential oil and gas source rocks throughout the state.

The amount of data housed in the DGGS GERILA database is impressive and continues to increase. As the amount and type of data changes, the database structure, organization, and software tools used to import, query, and extract information from the database must also be altered to meet the growing needs of DGGS scientists, academic and private researchers, and a variety of interested users. In order to meet those needs, careful planning and logical implementation is a must in an attempt to compensate for unforeseen requests and new future datasets. Database schema, organizational constraints, and data formats that may have been utilized in the past may not necessarily be valid or desired now. We at DGGS encourage users of our data to provide feedback regarding any aspect of our web site, data distribution policies, and data acquisition methods.

\section{REFERENCES CITED}

Davidson, Gail, 1998, Can We Get There from Here? Experiences of the Alaska Division of Geological \& Geophysical Surveys, in Soller, D.R., ed., Digital Mapping Techniques '98 - Workshop Proceedings: U.S. Geological Survey Open-File Report 98-487, p.13-14. http://pubs.usgs.gov/of/of98-487/davidson.html

Freeman, L.K., 2001a, The DGGS Geologic Database: Putting Geologic Data Modeling into Practice: Alaska Division of Geological \& Geophysical Surveys, Alaska GeoSurvey News, v. 5, no. 3, 3 p.

Freeman, L.K., 2001b, A Case Study in Database Design: The Alaska Geologic Database, in Soller, D.R., ed., Digital Mapping Techniques '01 - Workshop Proceedings: U.S. Geological Survey Open-File Report 01-223, p.31-34. http://pubs.usgs.gov/of/2001/ of01-223/freeman.html

Freeman, L.K., Engle, Kathryn, and Browne, Carrie, 2003, Alaska Division of Geological \& Geophysical Surveys Geologic Database Development - Logical Model, in Soller, D.R., ed., Digital Mapping Techniques '02 - Workshop Proceedings: U.S. Geological Survey Open-File Report 02-370, p. 157-160. http:// pubs.usgs.gov/of/2002/of02-370/freeman.html

$$
\begin{gathered}
\text { For a color, downloadable .pdf version of this newsletter please go to } \\
\text { http://www.dggs.dnr.state.ak.us/news.htm } \\
\text { or contact our office at (907)451-5020, } \\
\text { or by email to joni@dnr.state.ak.us. }
\end{gathered}
$$

\section{Dear Readers:}

Hello, friends of Alaska geology. There have been many changes in DGGS since you last read this newsletter, and I invite you all to stop by our offices or visit our website and check out our latest news and information.

Alaska is a very dynamic place with 'the norm' being defined by constant change. The staff at DGGS is committed to keeping pace with this changing environment, both geologically and geopolitically; a perfect example of this can be seen in the feature story published above. Kenneth Papp, an important new member of our Geologic Communications section, highlights recent changes and updates to our information and data distribution system. I urge you to keep in touch and take advantage of the information being generated by our many programs.

I am sad to announce we have had some staff retirements from state service to pursue other life interests; they will be sorely missed. However, we are equally excited for Karen Clautice and Ellen Harris as they move on to new adventures and experiences. On a positive note, we have been able to attract some excellent people to help us reach our goals: Geologists Marwan Wartes, Emily Finzel, Kate Bull, and Kenneth Papp; Microcomputer/Network Technician Fred Schikora; and Receptionist LeeAnne Kozie. These folks have already made major contributions to our effort and we are excited about the future. On the management front, Mark Myers has been appointed State Geologist and Director of the survey, (in addition to continuing as the Director of the Division of Oil \& Gas), I am now the Deputy Director for Research, and Rod Combellick has been appointed Associate Director in charge of operations. Please feel free to give any of us a call.

We have many projects underway that can be reviewed at your leisure on our website (www.dggs.dnr.state.ak.us), as well as some important changes on the horizon. Please stay tuned as we continue our effort to understand the complex geology of our state, and disseminate that information for planning, business development, public safety, and resource development. These are very exciting times, and we look forward to hearing from you.

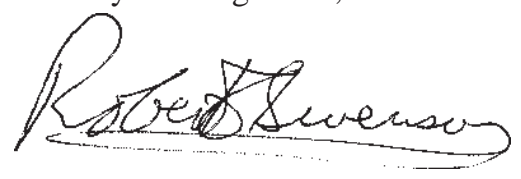

Robert Swenson

Deputy Director, Research

Department of Natural Resources

Division of Geological \& Geophysical Surveys

Division of Oil and Gas 


\section{ORDERING INFORMATION}

For each publication ordered, include both the publication title and number. Mail orders are payable in advance. Make check or money order in U.S. currency and payable to the State of Alaska. Credit cards are accepted. Telephone orders are accepted by the Fairbanks office between 8 a.m. and 5 p.m. Alaska time. Fax and email requests are accepted any time; these orders will be invoiced. If you would like to leave your order on voice mail, this can also be done 24 hours a day and you will be invoiced.

\section{SHIPPING \& HANDLING}

-Domestic postage - \$3.85 (Priority Mail flat rate) unless other arrangements are made.

-Canada and Mexico - \$7.00 (Global Priority Mail flat rate) unless other arrangements are made.

-All other international - Actual cost of postage. Please email or call for an exact amount or let us include an invoice for postage costs.

-For rolled-map orders requiring mailing tubes, include an additional \$3.50.

\section{WHERE TO ORDER}

Publications of the Division of Geological \& Geophysical Surveys are available over the counter, by mail, phone, fax, or email from the DGGS Fairbanks office:

ATTN: Geologic Communications Section-Publication Sales Alaska Division of Geological \& Geophysical Surveys 3354 College Rd.

Fairbanks, AK 99709-3703

(907) 451-5020 Fax (907) 451-5050

Email: dggspubs@dnr.state.ak.us

Prices of DGGS publications are subject to change. Increases in costs make it necessary to raise the selling prices of many publications offered. It is not feasible for DGGS to change the prices stated in previous announcements and publications in stock, so the prices charged may differ from the prices in the announcements and publications. Overpayments of \$2 or less will not be refunded. 


\section{NEW DGGS PUBLICATIONS}

\section{GEOPHYSICAL MAPS \& REPORTS}

GPR 2004_6. Line, gridded, and vector data, and selected plot files of the airborne geophysical survey data of the Nome mining district, Seward Peninsula, Alaska, by L.E. Burns, Fugro Airborne Surveys Corp., and Stevens Exploration Management Corp., 2004, 1 CD-ROM. Line data in ASCII format; gridded data in Geosoft and ER Mapper format; vector files in Autocad 13 dxf files. 6 maps listed below as GPR 2004_6_1a through 3b are included as plot files for in both HPGL/2 format and postscript printer format. Software is needed with ability to plot HPGL2 files for an HP Design Jet 5000/5500 series plotter or postscript files designed for an HP Design Jet Designjet 5000/5500 using Postscript 3 printer driver v5.0. The postscript files should plot on all Hewlett Packard plotters that can interpret Postscript 3 files. Supercedes PDF 94-15 and PDF 94-33. \$10.

GPR 2004_6_1a. Total magnetic field of the Nome mining district, Seward Peninsula, Alaska, by L.E. Burns, Fugro Airborne Surveys Corp., and Stevens Exploration Management Corp., 2004, 1 sheet, scale 1:63,360. Full color map; topography included. Supercedes RI 94-10; see also GPR 2004_6_1b. \$13.

GPR 2004_6_1b. Total magnetic field of the Nome mining district, Seward Peninsula, Alaska, by L.E. Burns, Fugro Airborne Surveys Corp., and Stevens Exploration Management Corp., 2004, 1 sheet, scale 1:63,360. Full color map; magnetic contours and section lines included. Supercedes RI 94-10; see also GPR 2004_6_1a. \$13.

GPR 2004_6_2a. $7200 \mathrm{~Hz}$ coplanar apparent resistivity of the Nome mining district, Seward Peninsula, Alaska, by L.E. Burns, Fugro Airborne Surveys Corp., and Stevens Exploration Management Corp., 2004, 1 sheet, scale 1:63,360. Full color map; topography included. Supercedes RI 94-12; see also GPR 2004_6_2b. \$13.

GPR 2004_6_2b. $7200 \mathrm{~Hz}$ coplanar apparent resistivity of the Nome mining district, Seward Peninsula, Alaska, by L.E. Burns, Fugro Airborne Surveys Corp., and Stevens Exploration Management Corp., 2004, 1 sheet, scale 1:63,360. Full color map; resistivity contours and section lines included. Supercedes RI 94-12; see also GPR 2004_6_2a. \$13.

GPR 2004_6_3a. $900 \mathrm{~Hz}$ coplanar apparent resistivity of the Nome mining district, Seward Peninsula, Alaska, by L.E. Burns, Fugro Airborne Surveys Corp., and Stevens Exploration Management Corp., 2004, 1 sheet, scale 1:63,360. Full color map; topography included. Supercedes RI 94-13; see also GPR 2004_6_3b. \$13.

GPR 2004_6_3b. $900 \mathrm{~Hz}$ coplanar apparent resistivity of the Nome mining district, Seward Peninsula, Alaska, by L.E. Burns, Fugro Airborne Surveys Corp., and Stevens Exploration Management Corp., 2004, 1 sheet, scale 1:63,360.
Full color map; Resistivity contours and section lines included. Supercedes RI 94-13; see also GPR 2004_6_3a. $\$ 13$.

\section{INFORMATION CIRCULARS}

IC 12. Services of the Alaska Division of Geological \& Geophysical Surveys, by D.R. Roberts, revised June 2005, 2 p. Free.

IC 50. Alaska's mineral industry 2004: a summary, by D.J. Szumigala and R.A. Hughes, 2005, 18 p. Free.

\section{PRELIMINARY INTERPRETIVE REPORT}

PIR 2005-1. Bristol Bay and Alaska Peninsula 2004: Fieldwork and sample analysis compilation report, by R.R. Reifenstuhl, R.D. Bailey, and E.S. Finzel, 2004, 20 p. \$2. PIR 2005-2. Architectural analysis of fluvial conglomerate in the Nanushuk Formation, Brooks Range Foothills, Alaska, by E.S. Finzel and P.J. McCarthy, 2005, 18 p. \$2. PIR 2005-3. Preliminary investigation of the Lisburne Group, upper Nanushuk River region, central Brooks Range, Alaska, by J.G. White, 2005, 28 p. \$3.

PIR 2005-4. Sedimentology, stratigraphy, and hydrocarbon reservoir-source rock potential, using surface and subsurface data, of Tertiary and Mesozoic strata, Bristol Bay Basin and Alaska Peninsula, by Emily S. Finzel, Rocky R. Reifenstuhl, Paul L. Decker, and Kenneth D. Ridgway, 2005, 66 p. \$7.

PIR 2005-5. Principal facts for gravity data collected in the northern Susitna Basin area, southcentral Alaska, by John F. Meyer, Jr., 200512 pl. \$2.

\section{RAW-DATA FILES}

RDF 2005-1. 30-meter shaded relief image of Okmok Volcano, Unmak Island, Alaska, by J.R. Schaefer, 2005, 1 CD. $\$ 10$.

RDF 2005-2. Major-oxide, minor-oxide, trace-element, and geochemical data from rocks collected in the Solomon, Bendeleben, and Nome Quadrangles, Seward Peninsula, Alaska in 2003 and 2004, by M.B. Werdon, D.J. Szumigala, R.J. Newberry, J.E. Athey, and S.A. Hicks, 2005, 46 p. \$5. RDF 2005-3. Latitudes and longitudes of volcanoes in Alaska, by C.E. Cameron, 2005, 1 CD. $\$ 10$.

RDF 2005-4. Geochemical data from reanalysis of streamsediment samples collected in 1982 from the Livengood area, Tolovana mining district, Alaska, by D.J. Szumigala, C.C. Puchner, and R.E. Myers, 2005, 45 p. \$5.

\section{REPORT OF INVESTIGATONS}

RI 2004-3. Preliminary volcano-hazard assessment for Okmok Volcano, Unmak Island, Alaska, by J.E. Begét, J.F. Larsen, C.A. Neal, C.J. Nye and J.R. Schaefer, 2005, 32 p., 1 sheet, scale 1:150,000. \$17. 


\section{STATE OF ALASKA \\ DEPARTMENT OF NATURAL RESOURCES \\ DIVISION OF GEOLOGICAL \& GEOPHYSICAL SURVEYS}

Mail order to:

Alaska Division of Geological \& Geophysical Surveys

Attn: Geologic Communications Section

3354 College Rd.

Fairbanks, Alaska 99709-3707
E-mail:dggspubs@dnr.state.ak.us

http://wwwdggs.dnr.state.ak.us

(907) 451-5020

Fax: (907) 451-5050

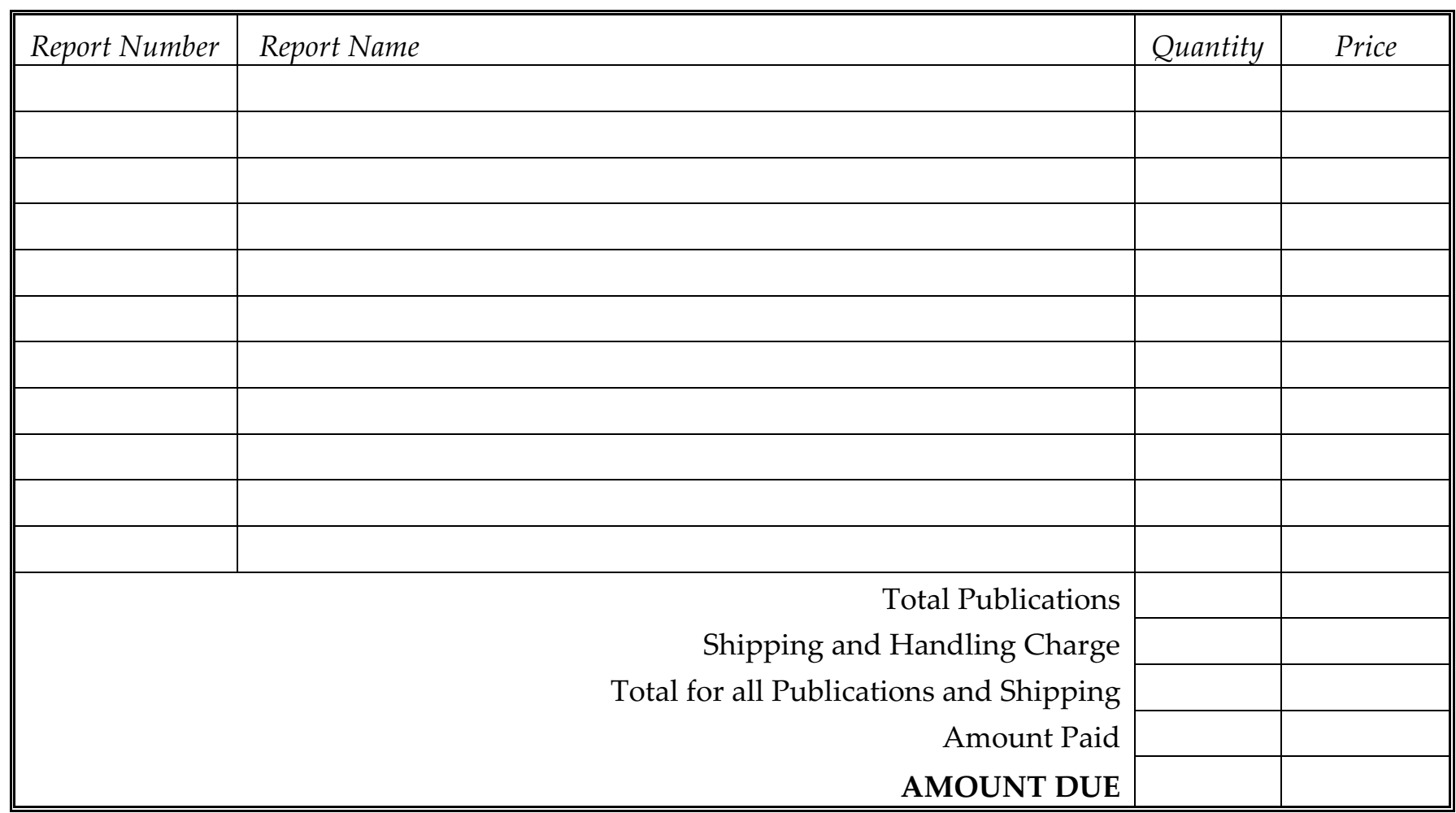

\section{POSTAGE}

Domestic postage: $\$ 3.95$ (Priority Mail flat rate) unless other arrangements are made.

Canada and Mexico: $\$ 7.00$ (Global Priority Mail flat rate) unless other arrangements are made.

All other International: Actual cost of postage. Please e-mail or call for an exact amount or let us include an invoice for postage costs.

\section{Ship publication(s) to:}

Name

Organization

Address

City, State Zip

Payment must accompany your order. Make check or money order payable to STATE OF ALASKA We accept Visa and MasterCard. For payment by credit card, please contact our office at (907) 451-5020. 